\title{
Abundance and behavior of the sally lightfoot crab (Grapsus grapsus) in the colony of the brown booby (Sula leucogaster) in the São Pedro and São Paulo Archipelago*
}

\author{
Dimas Gianuca $^{1}$ \& Carolus Maria Vooren ${ }^{1}$ \\ ${ }^{1}$ Laboratorio de Elasmobrânquios e Aves Marinhas, Departamento de Oceanografia \\ Universidade Federal de Río Grande (FURG), P.O.Box 474, 96201-900, Río Grande (RS), Brasil
}

\begin{abstract}
For nine days, the number of sally lightfoot crabs (Grapsus grapsus) in a $300 \mathrm{~m}^{2}$ area within the brown booby (Sula leucogaster) colony and the activity of each crab were recorded in the morning (5:30-7:30 h), at midday (11:30-13:30 $\mathrm{h}$ ), and in the afternoon (15:30-17:30 h). The average number of individuals was $80.2 \pm 15.5$ (59-111) in the morning, 3.1 $\pm 2.3(0-7)$ at midday, and $65.3 \pm 15(49-92)$ in the afternoon. A total of 1338 activity records were made, with the crabs standing still or walking in 844 records and handling material or feeding in 494 records. In the latter records, $53 \%$ of the crabs were handling detritus (pieces of dry bird excrement and sediment), 12.2\% were handling feathers, $12.8 \%$ were feeding on regurgitated fish, $8.9 \%$ were feeding on dead Sula leucogaster, $8.1 \%$ were feeding on crab, $4.7 \%$ were feeding on material adhered to egg shells, and $0.6 \%$ were feeding on live nestlings of S. leucogaster. The low frequency of crabs in the colony around noon shows that the crabs avoid insolation, hiding in shady places and tidal pools. In the São Pedro and São Paulo Archipelago, the presence of S. leucogaster represents an important food source for G. grapsus. This crab plays the role of a cleaner in the $S$. leucogaster colony, consuming food remains, broken eggs, and dead birds.
\end{abstract}

Key words: São Pedro and São Paulo Archipelago, Sula leucogaster, Grapsus grapsus, Brazil.

\section{Abundancia y comportamiento del cangrejo costero (Grapsus grapsus) en la colonia de piquero café (Sula leucogaster) en el archipiélago de São Pedro y São Paulo*}

RESUMEN. Durante nueve días se registró el número de cangrejos costeros (Grapsus grapsus) en una área de 300 m² dentro de la colonia de piquero café (Sula leucogaster) y la actividad de cada uno de los individuos durante la mañana (5:30-7:30 h), mediodía (11:30-13:30 h) y tarde (15:30-17:30 h). La media de individuos en la mañana fue 80,2 $\pm 15,5$ (59-111), en el mediodía 3,1 $\pm 2,3$ (0-7) y en la tarde 65,3 \pm 15 (49-92). Del total de 1.338 registros de comportamiento, 844 fueron de cangrejos detenidos o caminando y 494 manipulando algún material o alimento. De éstos, 53\% fueron de manipulación de detrito (excremento seco de ave y sedimento); 12,2\% de manipulación de plumas; 12,8\% alimentándose de peces regurgitados; $8,9 \%$ de un Sula muerto; $8,1 \%$ de cangrejo; $4,7 \%$ de material adherido a las cáscaras de huevos y $0,6 \%$ de cría de Sula viva. La baja frecuencia de los cangrejos en la colonia durante el mediodía es una evidencia que los mismos se protegen de la insolación, permaneciendo en la sombra y en pozas de marea. En el archipiélago de São Pedro y São Paulo la presencia de $S$. leucogaster representa una importante fuente de alimentación para G. grapsus, que desempeña un papel de limpiador en la colonia de esta ave, consumiendo restos de comida, huevos quebrados y aves muertas.

Palabras clave: archipiélago de São Pedro y São Paulo, Sula leucogaster, Grapsus grapsus, Brasil.

Corresponding author: Dimas Giamuca (dmsgianuca@hotmail.com)

* This work was presented at the XXV Congreso de Ciencias del Mar de Chile and the XI Congreso Latinoamericano de Ciencias del Mar (COLACMAR), in Viña del Mar, 16-20 May 2005. 
Grapus grapsus is a marine crab that inhabits rocky shores and islands of the Atlantic and Pacific coasts of the Americas. The species ranges from tropical latitudes in the Northern Hemisphere to temperate latitudes in the Southern Hemisphere (Rodríguez, 1980; Melo, 1996). Specimens can reach a total carapace length of $7.9 \mathrm{~cm}$ (Romero, 2003).

According to Romero (2003), in the bay of Ancón, Perú, G. grapsus feeds on cirripedes, mytilids, and porcelain crabs and occasionally acts as a scavenger. This crab also feeds on young sea turtles in the Brazilian Fernando de Noronha Islands (Bellini, 1996). In the Galapagos Islands, $G$. grapsus is a predator of newly hatched blue-footed boobies (Sula nebouxii) and masked boobies ( $S$. dactylatra).

Three species of marine birds nest in the São Pedro and São Paulo Archipelago: the brown or common noddy (Anous stolidus), the black noddy (A. minutus, Family Laridae), and the brown booby (Sula leucogaster, Sulidae). G. grapsus is numerous in this archipelago, where it circulates and forages amongst the bird nests (Darwin, 1891; Murphy, 1936; Nelson, 1978; Both \& Freitas, 2004; Cavalcanti, 2004). It also remains on the lookout, watching for opportunities to catch and devour newly hatched young (Both \& Freitas, 2004). Murphy (1936) and Nelson (1978) indicate that this crab is a threat to the young of the birds that nest in the São Pedro and São Paulo Archipelago.
The São Pedro and São Paulo Archipelago $\left(00^{\circ} 55^{\prime} 01^{\prime \prime} \mathrm{N}, 29^{\circ} 20^{\prime} 44^{\prime \prime} \mathrm{W}\right)$ is located $100 \mathrm{~km}$ north of the Equator and 1,010 km off the coast of Brazil (Fig. 1). It is made up of five small rocky islands with a total emerged area of $1.7 \mathrm{~km}^{2}$. The sun rises between 5:30 and 6:00 and sets between 17:45 and 18:15 local time (official time of Brasilia $+1 \mathrm{~h}$ ).

The S. leucogaster individuals are concentrated on Belmonte Island, where there is a breeding colony of around 170 pairs (Cavalcanti, 2004). This island is $100 \mathrm{~m}$ long, $60 \mathrm{~m}$ wide, and reaches $17 \mathrm{~m}$ in altitude; there is one house $\left(49 \mathrm{~m}^{2}\right)$ on the island that is always occupied. The area selected for the present study was located near the house, where the $S$. leucogaster nests are particularly abundant (Edwards et al., 1981; Both \& Thales, 2004). The nests are distributed on the rocky ground from approximately 2 to $16 \mathrm{~m}$ above the level of the high tide. The number of G. grapsus individuals and their activity were observed for nine days, from 17 to 25 August 2004, in an area of $300 \mathrm{~m}^{2}$ within the $S$. leucogaster colony, at three times: morning (5:30$7: 30 \mathrm{~h})$, midday (11:30-13:30 h), and afternoon (15:30-17:30 h). Abundance was measured as the average number of crabs at each sampling time. Variations in crab abundance between sampling times were studied using analysis of variance (ANOVA) and the Tukey test (Zar, 1999). The observations were done with the naked eye and the percentage of cloud cover was estimated daily.



Figure 1. Geographical location of São Pedro and São Paulo Archipelago. 
The nests within the study area were counted and a sample set of 30 nests was selected at random to determine nest content and estimate the percentage of brown booby pairs with recently hatched young in the colony. These 30 nests were monitored daily to evaluate the loss of eggs and young.

The presence of G. grapsus was verified in all the morning and afternoon observations, with respective averages of $80.2 \pm 15$ (59-111) and $65.3 \pm 15.5$ (4992) individuals; the highest density recorded was 0.37 crabs $\cdot \mathrm{m}^{-2}$. The average number of specimens at midday, $3.1 \pm 2.3(0-7)$, differed significantly $(\mathrm{p}<$ 0.001 ) from the morning and afternoon abundances (Fig. 2). The average daily cloud cover was $26.4 \%$ and the greatest crab abundance at midday was recorded on the cloudiest day of the study period (Fig. 3). Of a total of 1,338 behavior records, $63.1 \%$ were of crabs standing still or walking and $36.9 \%$ were of crabs manipulating some material or feeding. Seven items were identified that were explored by the crabs: detritus (dry bird excrement, sediment), $S$. leucogaster egg shells, S. leucogaster feathers, fish regurgitated by S. leucogaster, dead S. leucogaster, $S$. leucogaster young (recently hatched, live), and crabs (parts of G. grapsus) (Table 1). During the nine days of observations the crabs killed only one $S$. leucogaster chick, and this occurred outside the nest where this chick had hatched (Fig. 4).

A total of 115 nests were found in the study area. At the beginning of the observations, $16(33.3 \%)$ of the 30 nests monitored contained eggs and/or young: four nests had one egg and one young, five had one young, six had two eggs, and one nest had only one egg. Considering the ratio of 0.3 recently hatched young per nest, it was estimated that there were 34.5 recently hatched young in the study area when the observations began. The eggs in the nests with an egg and a nestling hatched during the study period. The youngest offspring survived between one and four days. No mortality was observed in nestlings without siblings. In two of the nests that contained two eggs, one of these was lost.

The scarcity of crabs in the colony at midday indicates that the crabs protect themselves from insolation at this time of day, hiding in shady areas and tidal pools. This hypothesis is supported by the abiotic data obtained in April 2001 by Medevedovski (2001); this author reported temperatures of the rocky soil in the study area that were $26-36^{\circ} \mathrm{C}$ in the morning $(6-9 \mathrm{~h}), 33-40^{\circ} \mathrm{C}$ at midday $(11-14 \mathrm{~h})$, and $26-34^{\circ} \mathrm{C}$ in the afternoon $(15-18 \mathrm{~h})$. The number of



Figure 2. Mean and standard deviation of the number of individuals of the crab Grapsus grapsus in the studied portion of the colony of the brown booby (Sula leucogaster) on Belmonte Island, São Pedro and São Paulo Archipelago, during nine days, at 5:30-7:30 $\mathrm{h}$ in the morning (m), at 11:30-13:30h in the mid-day (md) and at 15:30-17:30h in the afternoon $(t)$.

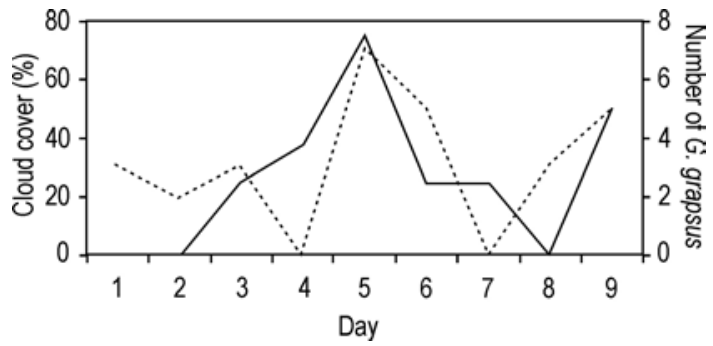

Figure 3. Daily cloud cover (solid line) and number of individuals of the crab Grapsus grapsus in the midday (broken line) during 17 to 25 August 2004, in the studied portion of the colony of the brown booby (Sula leucogaster) on Belmonte Island, São Pedro and São Paulo Archipelago.

G. grapsus was also reduced at midday in emerged sites along the Peruvian coast (Romero, 2003). The present study was carried out during the dry season (Innocentini et al., 2000); it is likely that reduced $G$. grapsus abundance at midday is less marked during the rainy season (February and March) when cloudy skies are predominant. S. leucogaster reproduces throughout the year (Nelson, 1978; Martins \& Dias, 2003; Branco, 2003; Both \& Freitas, 2004). During storms, waves reach the emerged part of Belmonte Island, destroying S. leucogaster nests and eggs and killing the young (Both \& Freitas, 2004; Cavalcanti, 2004). Such events provide the sally lightfoot crabs with abundant food.

Only one chick of S. leucogaster was killed by crabs during the present study. This number 


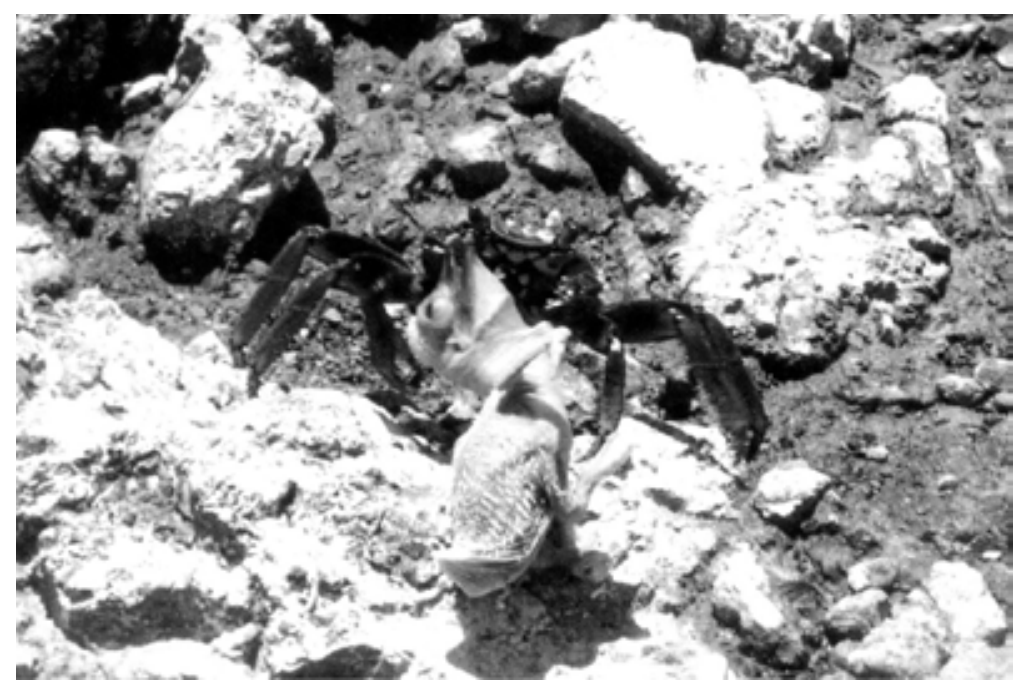

Figure 4. The sally ligthfoot crab Grapsus grapsus preying on a chick of the brown booby (Sula leucogaster) expelled from the nest on Belmonte Island, São Pedro and São Paulo Archipelago, on 21 August 2004.

Table 1. Items explored by the crab Grapsus grapsus in the studied portion of the colony of the brown booby (Sula leucogaster) on Belmonte Island, São Pedro and São Paulo Archipelago, and number of records for each item.

\begin{tabular}{lcc}
\hline & \multicolumn{2}{c}{ Frequency } \\
\cline { 2 - 3 } Ítems explored & Number of records & Percentage (\%) \\
\hline Dead crab & 40 & 8.1 \\
Egg shells & 23 & 4.7 \\
Debris & 261 & 53.0 \\
Feather & 60 & 12.2 \\
Regurgitated fish & 63 & 12.8 \\
Chick & 3 & 0.6 \\
Dead bird & 44 & 8.9 \\
\hline
\end{tabular}

is very low in view of the fact that 34 recently hatched chick where estimated in the study area. $S$. leucogaster usually lays two eggs and the two chicks hatch a few days apart. The second to be born is always expelled from the nest by the firstborn, characterizing this species as one of obligatory fratricide (Nelson, 1978; Both \& Freitas, 2004; Cavalcanti, 2004). Murphy (1936) and Nelson (1978) state that G. grapsus causes important mortality of $S$. leucogaster chicks. However the present study is evidence that on Belmonte Island the predation by G. grapsus occurs only on chicks expelled from the nest and therefore already eliminated from the reproductive process. Moreover, no mortality of nestlings without siblings was observed in the monitored nests. G. grapsus predation on chicks of the boobies $S$. dactylatra and $S$. nebouxii expelled from the nests was also reported in the Galapagos Islands (Lougheed \& Anderson, 1999). In spite of potential predators on these islands other than crabs (e.g., birds and snakes), the only proven cause of mortality in recently hatched $S$. dactylatra and $S$. nebouxii was fratricide due to the efficient parental care of the surviving nestling (Anderson \& Hodum, 1993; Lougheed \& Anderson, 1999). On the other hand, on Belmonte Island, crabs may steal eggs and young from the nests when the colony is disturbed by humans (Darwin, 1891; Nelson, 1978).

The S. leucogaster colony on Belmonte Island represents a important food source for G. grapsus and may contribute to the abundance of these crabs 
in the area (up to 37 individuals $100 \mathrm{~m}^{-2}$ ), which is greater than the abundance found on Mexican islands (maximum 12 individuals $100 \mathrm{~m}^{-2}$ ) (MillePagaza et al., 2003) and along the coast of Peru (up to 70 individuals along $100 \mathrm{~m}$ of rocky coastline) (Soto et al., 2002). This crustacean plays a cleaning role in the S. leucogaster colony, feeding on the organic matter that otherwise would accumulate in the area. Experiments of G. grapsus exclusion from nesting areas would allow us to study up to what point this crustacean has a positive or negative influence on the reproductive success of $S$. leucogaster on Belmonte Island.

\section{ACKNOWLEDGEMENTS}

The authors thank the "Secretaria da Comissão Interministerial para os Recursos do Mar (SECIRM)" for logistic and financial support of the project "Monitoramento das aves do Arquipélago de São Pedro e São Paulo", with which this work is connected. They are also grateful to Paula Laporta and Silvina Botta for help with the Spanish language.

\section{REFERENCIAS}

Anderson, D.J. \& J.P. Hodum. 1993. Predator behavior favors clumped nesting in an oceanic seabird. Ecology, 74(8): 2462-2464.

Bellini, C. 1996. Reproduction and feeding of marine turtles in Fernando de Noronha Archipelago, Brazil. Mar. Turtle Newsl., 74: 12-13.

Branco, J.O. 2003. Reprodução das aves marinhas nas ilhas costeiras de Santa Catarina, Brasil. Rev. Bras. Zool., 20(4): 619-623.

Both, R. \& T.O.R. Freitas. 2004. Aves marinhas no arquipélago de São Pedro e São Paulo. pp. 193212 In: J. O. Branco (ed.). Aves marinhas insulares brasileiras: bioecologia e conservação. Editora da UNIVALI, Itajaí, pp. 193-212.

Cavalcanti, R.B.F. 2004. Abundância, estrutura etária e reprodução do atobá-marrom (Sula leucogaster) no arquipélago de São Pedro e São Paulo, Brasil. Fundação Universidade do Rio Grande: Dissertação de mestrado. Rio Grande, RS, 146 pp.

Darwin, C. 1891. Journal of researches into the natural hystory and geology of the countries visited during the voyage of H.M.S. Beagle round the world. Ward, Lock \& Co., London, 492 pp.

Edwards, A.J., K. Wilson \& H. Hubbock. 1981. The sea-bird population of St Paul's Rocks. Ibis, 123: 233-238.

Harrison, P. 1983. Seabirds. An identification guide. Houghton Mifflin, Boston, 448 pp.

Innocentini, V., C.S. Prado, F. Pereira \& N. Brandão. 2000. Marulhos no litoral norte do Brasil gerados por furacões: Caso de 24 de outubro de 1999. Rev. Bras. Meteorol., 16(2): 177-186

Lougheed, L.W. \& D.J. Anderson. 1999. Parent blue-footed boobies suppress siblicidal behavior of offspring. Behav. Ecol. Sociobiol., 45: 11-18.

Martins, F.C. \& M.M. Dias. 2003. Cuidado parental de Sula leucogaster (Boddaert, 1783) (Pelicaniformes, Sulidae) nas Ilhas dos Currais, Paraná, Brasil. Rev. Bras. Zool., 20(4): 583-589.

Melo, G.A.S. 1996. Manual de identificação dos Brachyura (caranguejos e siris) do litoral brasileiro. Editora Plêiade, Jabaquara, 603 pp.

Medvedovski, I.G. 2001. Monitoramento da avifauna do arquipélago de São Pedro e São Paulo. Relatório das atividades da expedição 084 (Unpublished).

Mille-Pagaza, S., A. Peres-Chi \& M.E. SánchesSalazar. 2003. Littoral decapods of Socorro Island, Revillagigedo Archipelago, Mexico. Rev. Biol. Trop., 51(1): 175-182.

Murphy, R.C. 1936. Oceanic birds of South América, 2. The American Museum of Natural History, New York, $1586 \mathrm{pp}$.

Nelson, B.J. 1978. The Sulidae. Gannets and boobies. Oxford University Press, Oxford, 1012 pp.

Romero, L. 2003. Comportamiento reproductivo y mutilaciones en el cangrejo de las rocas Grapsus grapsus (Linnaeus, 1758) (Crustacea, Decapoda). Rev. Perú. Biol., 10(2): 195-202.

Rodriguez, G. 1980. Los crustáceos decápodos de Venezuela. Instituto Venezolano de Investigaciones Científicas, Caracas, 512 pp.

Soto, R.M., S.M. Muñoz \& S.A. Moreno. 2002. Biological background of "El Niño" and "La Niña" in intertidal and subtidal communities of northern zone of Chile. Invest. Mar., Valparaíso, 30(1): 160-162.

Zar, J.H. 1999. Biostatistical analysis. Prentice Hall, New Jersey, 931 pp. 
